DOI: 10.1515/auseur-2016-0019

\title{
Hungarian Culture of Philosophy and Historiography of Philosophy in Transylvania
}

\author{
Márton TONK \\ Department of International Relations and European Studies \\ Sapientia University, Cluj-Napoca \\ tonkmarci@sapientia.ro
}

\begin{abstract}
The first part of the study debates the role and the status of philosophy in the Hungarian culture in Transylvania, trying to explain why philosophy has not become an organic part of the Transylvanian culture as a whole. There are presented a few experimental and theoretical arguments, especially the theory of the so-called 'short philosophical traditon'. The second part the paper seeks to analyse the impact of the 'short philosophical tradition' on the current philosophy life in Transylvania, bringing an overwiew of the institutional structure of Hungarian philosophy in Transylvania. ${ }^{1}$
\end{abstract}

Keywords: minority (Hungarian) philosophy in Transylvania, literaryhistorical culture vs philosophical culture, the fragmentation of the Eastern European culture and the 'short philosophical tradition', periods of Hungarian philosophy in Transylvania (1880-1920, the period between the two world wars; the communist period; philosophy after 1989), philosophy life in our days: institutions, periodicals, publishers

Investigations referring to the past and present of philosophy and the history of philosophy in the Hungarian language in Transylvania sooner or later must necessarily take into consideration the role and status of philosophy in our culture - especially when such analyses are formulated within the environment of general researches of Hungarian Studies. Is philosophy present today in Hungarian culture and, within it, in Transylvanian culture? Is the philosophical thought an integrant part of our intellectual life, our cultural public sphere? Has philosophy become an organic part of our culture? What is the status and the role of philosophy in our public thinking? To what degree has the philosophical past become part of our collective recollection? In short: is philosophy at home today in Transylvanian Hungarian culture?

1 The first version of the present study was published in Márton Tonk: Minority and Community. Studies on the History, Theory and Educational Policy of the Hungarian Minority of Transylvania. The Romanian Institute of National Minorities, Cluj-Napoca, 2014, 39-53. 
If we wish to give a brief answer to this question now, then we could say that philosophy is not really present in Transylvanian culture, which does not contain the 'familiarity' of philosophy, and philosophy has not become an organic part of our culture as a whole. In our cultural-intellectual public sphere, we rarely meet references to the philosophical past and present, and perhaps even more rarely face the propagation and enforcement of the role and function of philosophy. Philosophy is simply not present in our scientific life in a wider sense, and generally neither in our cultural public sphere. A whole series of examples and connected explanations can be given to sustain this state of affairs. One of the most often mentioned reasons for the deficient cultural status of philosophy is, for example, that we are fundamentally a literary-historical culture, the characters and the creations of our imaginative literature and history make up the most considerable part of our collective recollection, and in the cultural-intellectual discourses of our days we significantly draw our explanatory and legitimating arguments from these areas. This statement (and state of affairs) has got a special weight with relation to the 'conservative' Transylvanian Hungarian society, which is, at the same time, in a defensive situation as a minority, and, undoubtedly, it also greatly influences the cultural role of philosophy. In this context, it is not at all surprising that in 2004, on the occasion of the $10^{\text {th }}$ anniversary of the existence of the philosophy journal entitled Kellék, appeared in Cluj (Kolozsvár), the editors placed the following statement as a short summary of the role and function of the publication on the cover of the jubilee number: 'We wished to speak to a medium that is not hostile towards philosophy, only indifferent." ${ }^{\prime 2}$ It is perhaps this indifference that most precisely paraphrases the relationship of Transylvanian Hungarian culture to philosophy - and, at the same time, it explains why the philosophical tradition, which is more difficult to digest anyway, did not become an organic part of our culture.

When identifying the place and the role occupied by philosophy in our culture, or the degree to which it has become an organic part of our culture, an excellent tool available for university instructors can be the quick assessment of the level of knowledge of the students about philosophy, more precisely about Hungarian philosophy. For the past two decades, the author of the present writing has also been teaching the history of Hungarian philosophy in several Transylvanian higher education institutions, ${ }^{3}$ and his general experience is that students practically do not have either knowledge or information about the past

2 The 2004/25. anniversary issue of the review appeared under the title of 'Best of Kellék', and it includes a representative selection from earlier issues. The philosophical periodical in Transylvania, which is, at the same time, one of the 'handful' of such periodicals appearing in the Hungarian language area still appears with a number of 53 issues published until now.

3 Reference is being made to the philosophy programme of Babeş-Bolyai University and Partium Christian University in Oradea (Nagyvárad) and to the European Studies programme of the Cluj (Kolozsvár) Faculty of Sapientia Hungarian University of Transylvania. 
of Hungarian philosophy, and the plain mentioning of the name of a Hungarian thinker means a pleasing exception. The situation is different, of course, if we ask about the literature and historical past of Transylvania. Here, even students at a lower level of knowledge are able to report in several sentences about a piece of our literature, an event of our history, or about some outstanding literary-historical personality. All this may be an experimental argument for the statement that Hungarian culture is primarily literary; and, at the same time, it reflects well the lack of 'familiarity' and integration of the culture of philosophy into Transylvanian Hungarian culture.

The fact that philosophy fails to be part of a wide public sphere, of culture in a general sense, and of public consciousness can be demonstrated through manifold examples, just as pertaining arguments meant to - mostly accurately - explain this state of affairs can be easily extended. Among these, we wish to formulate only one - though in our view very important - argument, which tries to explain the present situation of the Hungarian (Transylvanian) culture of philosophy from a narrower philosophical and history of philosophy viewpoint. Simultaneously with the problem of the cultural integration of philosophy, we must also ask the questions: what in fact needs to become an organic part of the Transylvanian Hungarian intellectual life and what exactly are the philosophical contents the presence of which we miss from the whole of our culture, cultural public sphere, and from the education of our students. In other words: what kind of a past, what kind of traditions has philosophy got in Transylvania? Since when may we talk about philosophy in Transylvania altogether? And with that question we have just rephrased - in a narrower, Transylvanian connection one of the general problems of Hungarian philosophical historiography, a debate upon which up until today no consensus has ever been reached in specialist circles, i.e.: since when can we speak about independent Hungarian philosophy at all? What does the tradition include and which is the period in the history of thinking, which in a comprehensive sense may be called the history of Hungarian philosophy? How far, respectively, how deep do our philosophical traditions reach, and - again - what is it that should (have) become part of our culture? We will see that responding to this question carries a very important explanation for the current, 'neglected' situation of the Transylvanian culture of philosophy and also the outlining of the tasks and challenges in front of the pursuers and institutions of philosophy.

The canonization endeavours concerning the history of Hungarian philosophy can be fundamentally grouped around two important standpoints. The history of our philosophy dates back to several centuries according to the first standpoint, with its beginning placed somewhere in the decades of the $17^{\text {th }}$ century, primarily around the oeuvre of János Apáczai Csere. According to the second viewpoint, on the other hand, this story covers a much shorter span of time: it can be roughly 
derived from the turn of the $19^{\text {th }}$ and $20^{\text {th }}$ centuries and it begins with the oeuvre of Károly Böhm, the first important systematizer of Hungarian philosophical thinking. About the first variant, it can be undoubtedly related that it is based on the widest interpretation of philosophy and historiography of philosophy, and it includes into the history of Hungarian thinking a number of developments that had occurred in Hungarian language area, but which essentially belong to the history of ideas, culture, and reception. On grounds of this definition, the previously mentioned Apáczai becomes one of the first Hungarian philosophers, as a local herald and diffuser of the Cartesian ideas of the age, making it possible at the same time for an author, who could hardly be considered a 'philosopher' in the sense of professional philosophy, to take his place in the Pantheon of the Hungarian history of philosophy. We do not wish to challenge the undoubtable merits of Apáczai and his significance from the point of view of reception history, we merely try to ask the question whether it is possible here to talk about history of philosophy in the proper sense of the discipline without having at least an independent philosophical thought or creation. And another, possibly even more thought-provoking doubt: are we observing narrower professional (philosophical, philosophical history) aims or do we have entirely different objectives when we try to 'document' ourselves and our nation reaching back to centuries in the long history of universal thinking? Do we not exchange scientific objectivity for a certain type of national self-justification and derive demonstrative philosophical historiography? And do our doubts not turn even stronger when reading such works of philosophical history as the one written by János Erdélyi, who, in his volume entitled Philosophy in Hungary, published in 1885, starts to discuss our history of philosophy with the Admonitions of King Saint Stephen written to his son, Prince Imre: 'Stephen, the first king of the Hungarians, the first philosopher of the Hungarians' (Erdélyi 1885: 10). ${ }^{4}$

The second approach to describe the nature, contents, and periods of the Hungarian philosophical past successfully goes around the dangers of demonstrative philosophical historiography, but it also defines a much shorter period of time as the history of Hungarian philosophy, only covering some 130-140 years. Starting from a much narrower defintion of the history of philosophy than the former one, puts the beginnings of independent Hungarian philosophy to the turn of the $19^{\text {th }} / 20^{\text {th }}$ century. The keynote of this idea belongs to the first important representative of the $20^{\text {th }}$ century 'renaissance of Hungarian philosophical historiography', Tibor Hanák, who unambiguously argues in

4 Some of the researchers of Hungarian philosophy have also already called attention to the existence of demonstrative philosophical historiography. For instance, Béla Mester writes the following in his volume entitled Magyar philosophia (Hungarian Philosophy): 'There exists a demonstrative philosophical historiography, which tries to show a "healthy" national culture that must necessarily include philosophy. We have to show that we have got it, too' (Mester 2006: 28). 
favour of a 'short' philosophical past. 'Until the end of the last century [i.e. the $\left.19^{\text {th }} / 20^{\text {th }}\right]$, Hungarian philosophy consisted of some isolated undertakings, the work a few excellent teachers, a number of good educational books, and the scholastic philosophy teaching of the theological seminaries' (Hanák 1980: 20). Or elsewhere: Hungarian culture only got to the stage 'when the institutional conditions necessary for the study of philosophy took shape at the turn of the century' (Hanák 1980: 22). And it is true indeed that a series of important events confirm the point of view that decisive steps were taken in the evolution of Hungarian philosophy and philosophy life at the turn of the century: around 1880, our first system-creating philosopher, Károly Böhm, starts publishing his work entitled Man and his World, which - in accordance with its author's endeavour - is indeed the first Hungarian philosophical system; in 1881, Alexander Bernát and József Bánóczi start the Hungarian-language edition of the classical authors of philosophy, the Collection of Philosophical Writers, and in the same year Károly Böhm lays the foundations of the Magyar Philosophiai Szemle (Hungarian Review of Philosophy); these are the years when the first philosophy department is established at the Budapest University (1895), and immediately following the turn of the century, in 1901, the Hungarian Philosophical Society also comes into existence. And although it cannot be connected to actual years, this is the period when modern Hungarian philosophical language or, as we would call it today, our academic terminology takes shape. ${ }^{5}$ Transylvanian philosophical and history of philosophy developments are naturally tightly connected to these events: in 1896, the Kantian/Fichtean Károly Böhm becomes a full professor of philosophy at the University of Kolozsvár, and not much later one of the most important philosophical centres of Hungarian philosophy, the so-called 'Kolozsvár School of Thought' begins to take shape around him.

All in all, the happenings in the field of philosophy at the turn of the $19^{\text {th }} / 20^{\text {th }}$ centuries, the regularity of the events of the forming philosophy life, the welldelineated directions of institutionalization (professional society, university, journal, book publisher etc.), the connections with the contemporary tendencies of philosophy, and, not the least, the birth of Hungarian philosophical creations carrying an independent message, all these lead to the conclusion that there is a sharp borderline in the history of Hungarian thinking and within it in the history of the culture of philosophy between the years preceding the 1880s and the period following it. We believe that - although the events and 'creations' of a philosophical nature in the period preceding the end of the $19^{\text {th }}$ century had most important cultural and social returns (and in this respect we can also accept the benefits of demonstrative philosophical historiography) - under the history

5 The Szeged-based researcher of Hungarian philosophy history, Sándor Laczkó, published a thorough study about the issue, entitled The Evolution of Hungarian Philosophical Terminology from the Time of Apáczai until the Turn of the $19^{\text {th }} / 20^{\text {th }}$ Centuries (Laczkó 2004). 
of Hungarian philosophy, we can in the best case understand the narrow time span of one and a half centuries between the previous turn of the century and our days. Answering our question brought up earlier: this means the historical perspective that constitutes the actual tradition of Hungarian philosophy, the character and quality of the philosophical works born in this period represent the really significant depths of our philosophy; this is the tradition, which is expected to become an organic part of Hungarian culture.

Accepting these statements, additional inferences can be formulated regarding the present situation and status of philosophy within culture. Applying a historical, cultural, universal philosophical history scale, we reach to the conclusion that we only possess a short philosophical tradition of our own, and this state of affairs is certainly not very much in favour of the cultural integration of philosophy or of its role and effects in the social-intellectual public sphere. At the same time, in a Transylvanian context - in addition to the narrow tradition of independent Hungarian philosophy -, another very important factor, different from the situation in Hungary, acted against the cultural-social 'integration' of philosophy: the fragmentation of Transylvanian philosophy life and the periodicity of Transylvanian philosophical traditions. This explains why 'the culture of philosophy could never become an organic part of the Transylvanian intellectual processes and it did not integrate into Transylvanian Hungarian culture. With respect to these structural and content deficiencies, the Transylvanian Hungarian culture generally shared the common misery of the culture of other Eastern European people' (Demeter-Tonk-Veress 2002: 207).

What does this fragmentation, periodicity of Transylvanian tradition mean in fact? If we survey the 130-140 years of the history of Hungarian philosophy from a Transylvanian perspective, four bigger philosophical history/thematic periods can be delineated. The first one lasts from the years before the turn of the century until Trianon, respectively the change of supremacy, and from a philosophical viewpoint it is characterized by some kind of a 'clear', regular philosophy, the discussion of the big topics of philosophical thinking independent in space and time (epistemological, ontological, axiological, ethical, and metaphysical questions); and the keynote of its investigations, its intellectual environment not surprisingly - are given and defined by contemporary German philosophy, the paradigms of the Kantianism, Fichteanism, and Neo-Kantianism. The work of the already mentioned Károly Böhm, aiming to create a 'clear philosophical system', the strong connections of his oeuvre to the city of Kolozsvár (Cluj) all fall into this period: between 1896 and 1911, he was Professor at the Franz Joseph University of Kolozsvár, an institution already recognized in Europe, but at the same time he was also a defining personality of Transylvanian culture and intellectual life. The great jurist of the turn of the century, Lajos Králik, writes beautifully about his deep relationship to Kolozsvár and the University: 'The academic life of 
Kolozsvár was a big blessing for Böhm. [...] He revived. [...] The teaching staff of the University of Kolozsvár may proudly and confidently acknowledge the fact that they recognized Böhm's strength, and invited this strength in an appropriate manner to a most suitable place, the chair of a university professor. The country owes thanks to the teaching staff of the University of Kolozsvár for what they have done by inviting Károly Böhm. Böhm's gratitude is a known fact. He told me: "Kolozsvár was a great luck to me! I started to live a new, illustrious life!”' (Králik 1913: 356). As a university professor, a school founding philosopher, institution and journal founder, he did not merely play an outstanding role in the history of Hungarian philosophy but also in the entire Transylvanian cultural history. At a young age, he set his own programme to create the Hungarian national philosophy, and he represented it throughout his life with tenacious perseverance - and the first uniform philosophical system of Hungarian philosophy, reflecting the spirit of the syntheses of the $19^{\text {th }}$ century in his paradigms and contents, came into existence along this endeavour (see Egyed 2000: 8).

The following period of the history of Transylvanian Hungarian philosophy is the period between the two world wars, the most significant feature of which is its turning from systematic philosophical questions towards the investigations aimed at the current problems of minority existence and culture. The radically changed political situation of the Transylvanian Hungarian community naturally brought the modification of the raised philosophical questions, and at the same time the still quite apparent effects of German philosophy were supplemented with the reception and topics of German existentialist philosophy. This latter aspect is well demonstrated by the thinking of the Cluj-based (Kolozsvár) Böhm school of thought, the major intellectual school of the period. The leading figures of the 'Kolozsvár School of Thought', or the 'Kolozsvár Böhm School', which by today has been proven to have great significance in the history of philosophy and history of ideas in the Hungarian language area, and has been canonized as such in circles of philosophical historians since the turn of the millennium - György Bartók, Sándor Kibédi Varga, György Kristóf, Sándor Makkai, László Ravasz, Béla Tankó, Sándor Tavaszy, and Béla Varga were in many ways defining personalities of Transylvanian intellectual-philosophy life for several generations. ${ }^{6}$ Their thinking is generally characterized by the 'adaptation' of

6 The circle of the Böhm disciples in Cluj (Kolozsvár) was probably firstly defined as an independent intellectual centre, a school of thought by Sándor Makkai himself (see Makkai 1925), and the group was later called 'the Transylvanian school of thought' by Sándor Kibédi Varga (see Kibédi Varga 1980). It is significant for the date of canonization in the Hungarian history of philosophy, of the 'Kolozsvár school', that, in 2000, the volume including the lectures of the 1996 'Károly Böhm International Scientific Conference' is published with the following title: Károly Böhm and the 'Kolozsvár School of Thought', and that, in 2003, a separate volume is published by Ildikó Veres, entitled: The Kolozsvár School of Thought. The author of the present study has dealt in detail with the role of the Böhm School of Thought in Kolozsvár and the evaluation of its philosophical aspects in his volume entitled Idealizmus és egzisztenciafilozófia 
the contents of universal and contemporary European philosophy to analyse the problems of Transylvanian Hungarian culture, education and society, and for the ontological, ethical and axiological investigation of minority existence. 'They were not only looking for the theoretical solutions of minority existence, but, as practising clergymen, later as bishops or deputy bishops, but also in the bustling intellectual daily life, as teachers, publicists, members or leaders of various organizations, editorial offices, they were the active shapers of the reality after Trianon' (Veress 2003: 7). By attempting to catch the category of minority existence with the help of ontological or ethical-moral premises and by trying to draw practical conclusions from the analysed concept, the philosophers of the school of Kolozsvár represented some kind of ontological-moral minority theory, as opposed to such figures of Transylvanian thinking between the two world wars as Arthúr Balogh, Elemér Jakabbfy, or Bódog Somló. The latters represented a minority rights attitude and political philosophy, which can be called classical, and according to which the status and the situation of minorities are to be interpreted in the framework of the principles of the constitutional state and the constitutional rule of law. Still, as creators of the second period in the history of Transylvanian Hungarian philosophy, the common feature of their thinking is the prominence of theoretical reflection, aimed at minority existence and culture.

The continuity of Transylvanian philosophical thinking broke again with the communist political transformation following World War II. Ideological absolutism, non-existent philosophical public sphere, the strongly restricted reception of universal philosophical creations and contents due to geographical/intellectual isolation, and generally a political and ideological terror, making independent philosophical creation impossible, were characteristic of the philosophy in the period of political transformation. In this period of Romanian (Transylvanian) socialism, philosophical reflection - withdrawn into the inner space of the thinking - was still capable of presenting indisputable contents and results; it is enough to mention here the oeuvre of the tragical philosopher hero, who can also be considered typical for the period, György Bretter. The importance of his personality and oeuvre, his role played in the Transylvanian Hungarian thinking is perhaps well demonstrated by the fact that - although there is no such canonization in Hungarian philosophical historiography - his disciples and friends living today sometimes define themselves as 'the carriers of his legacy', or philosophers who belong to the 'Bretter school'.

Finally, the most recent period of the history of Transylvanian philosophy is the period beginning with the 1989 political transformation, which is characterized by the reawakening of philosophy life, by a philosophical 'close-up', and the reorganization of the fundamental institutions of philosophy life.

Tavaszy Sándor gondolkodásában (Idealism and Existentialist Philosophy in the Thought of Sándor Tavaszy) (Tonk 2002), and in the study The Reception of Kant by Sándor Tavaszy and The Klausenburg School (Tonk 2015). 
The philosophical activity of the 90s was primarily characterized by the seeking for paths and places. This, on the one hand, expressed itself in the endeavours to catch up with the events and processes of philosophy life in Hungary and generally in Europe, and in the reception of research directions, questions raised, and results achieved, and, on the other hand, in the endeavours aimed to make adequate conditions for independent research activity and creation, to find a special voice and place in Transylvanian Hungarian culture and in the wider context of philosophy life. These endeavours were necessarily associated with efforts of institution building, and connection establishment (Demeter-Tonk-Veress 2002: 210).

As a summary of this brief overview of Transylvanian philosophical tradition, it can be concluded that our tradition is not too continuous historically, politically, or even contentwise, but it is rather divided into sections and plentiful in breaks and turning points. If we add to this fact the hypothesis of the 'short', one-hundred-/one-hundred-and-fifty-year-long Hungarian (and within it Transylvanian) philosophical past, we may get closer to answer the question why philosophy failed to become an organic part of our intellectual life or how come it is not 'at home' within the Transylvanian culture of our days.

But what do the philosophy life of our days and its institutional system consist of in Transylvania? What are the results of the reawakening that followed the political transformations of 1989, and how successfully were the institutions of the philosophy life reorganized? An important realization of the past two decades was the restarting and reorganization of university-level philosophy teaching and research, as the result of which there are currently two higher educational institutions with philosophy education, the Cluj-based (Kolozsvár) Babeş-Bolyai University and Partium Christian University in Oradea (Nagyvárad). Philosophy education has been operational since 1990 in Cluj (Kolozsvár); by now, it provides all the levels (BSc, MA, PhD), whereas in Oradea (Nagyvárad) the academic programme of philosophy started in 1999, but it currently offers education only at the MA level. The reorganization and establishment of university-level institutions of Transylvanian philosophical education in the Hungarian language turned into a most important factor for the formation of academic workshops of philosophy, but at the same time also in ensuring the continuity and quality of high-school philosophy education.

Besides the educational-scientific activity carried out within the universities' framework, the publishing of specialist books and reviews are equally important factors of Transylvanian philosophy life. Kellék, the already cited philosophical review, has been continuously published as a specialized journal in philosophy since 1994 by the Pro Philosophia Foundation and the Publishing House of Cluj (Kolozsvár), and a few years ago a new philosophical periodical (entitled Többlet) was published in Cluj (Kolozsvár) as the initiative of the Transylvanian 
Philosophical Society. As far as the publication of specialized books is concerned, after the political transformations of 1989, the publication of philosophical works increasingly gained ground, resulting in a series of Transylvanian publishers bringing out philosophical works besides the Pro Philosophia Publishing House, which prints exclusively philosophical works: Komp-Press - the publisher of the Korunk Friendly Association, Mentor, Scientia, BBU - University Press, the publishing houses of the Transylvanian Museum Society and of the Bolyai Society, etc. The Pro Philosophia Publishing House, operating as a specialized philosophy publisher, and as such functioning as an important centre for the popularization of Transylvanian philosophy culture has been in existence since 1999; its publications are grouped along two big thematic blocks: The Sources of Philosophical Literature in the Hungarian Language series and the Workshop series. The aim of the latter is to publish the works of contemporary Transylvanian Hungarian authors pursuing philosophy and philosophy teaching, hereby striving for the popularization of philosophy and seeking to increase the role, function, and prestige of philosophy in Transylvanian culture. The primary aim of The Sources of Philosophical Literature in the Hungarian Language publication series is to connect Hungarian (and particularly Transylvanian) philosophy tradition into the public spaces of culture and education: it publishes the critical text editions of 'forgotten' authors, who played a significant role in a certain period of our philosophical past, but it also brings out monographs valuing the oeuvre of these philosophers, contributing to the writing of the history of Hungarian philosophy. The ‘forgotten' works of Bódog Somló, Sándor Tavaszy, György Bartók, Pál Sipos, József Halasy-Nagy, György Bretter, or their works left in manuscripts never having appeared before were critically adapted and published within the framework of the series, and at the same time monographs and studies were also born on the philosophy of Károly Böhm, Sándor Makkai, Sándor Tavaszy, Gusztáv Szontagh, János Asbóth, and György Bretter, presenting new directions and opportunities for philosophy research in the Hungarian language.

Finally, let us cast a short glance at the professional institutions and associations of today's Transylvanian philosophy life - as besides university training and academic publications these are the most important fora for the public life of philosophy. There are currently three - Cluj-based (Kolozsvár) - organizations in the Transylvanian Hungarian institutional system, which strive to promote and represent the culture of philosophy, organize and manage philosophy life, and generally aim for the professional/social representation of philosophy: the already mentioned Pro Philosophia Foundation has been functioning since 1997; the independent Philosophy Department within the framework of the Regional Committee in Kolozsvár of the Hungarian Academy of Sciences, the first institution of the Academy outside the borders of Hungary that came into existence in 2008; and, finally, in 2009, the Transylvanian Hungarian Philosophical Society was also 
founded. It is not our aim here either to present the scopes of activity and the portfolios of the three institutions or to point out the differences, peculiarities that exist indeed in certain respects between the basic objectives of the operation of each and every organization. However, the obvious kinships and samenesses caught in the fundamental philosophical objectives and, at the same time, the personal parallelisms found within the institutions' internal lives and activities - which are inevitable considering the reduced number of the representatives of Transylvanian Hungarian philosophy - impose serious tasks upon our academic institutions. The concentration of the resources of the philosophical institutions functioning in a complex structure, made up of several frameworks and implying different strategies, the co-ordination of their activities, the parallel financial and professional-scientific sustainability of the organizations, and generally the rationality of the present status quo can be formulated as the big challenges of the present and the immediate future. Of course, the coin has a reverse side, too: at the turn of the past century - as we have seen earlier - exactly the largescale institutional variety, the complex lines of force of philosophical activity yielded a much more essential development, which looked rather uniform in its consequences: the development of the actual Hungarian philosophy life and within it that of the independent Hungarian philosophy, and the integration of philosophy within Hungarian culture. Let us hope, therefore, that upon a new turn of a century history repeats itself and that the Transylvanian philosophy life and diversified professional system of institutions born around the turn of the $20^{\text {th }} / 21^{\text {st }}$ centuries briefly presented above will again work in a unified direction, along the same line of force, if not else, then, at least, in the direction of the 'organic' integration of philosophy into the Transylvanian Hungarian culture and education.

\section{References}

DEMETER, M. Attila-TONK, Márton-VERESS, Károly. 2002. Az erdélyi magyar filozófia a XX. század utolsó évtizedében (Transylvanian Hungarian Philosophy in the Last Decade of the $20^{\text {th }}$ Century). In: Tánczos, Vilmos-Tókés, Gyöngyvér (eds), Tizenkét év. Összefoglaló tanulmányok az erdélyi magyar tudományos kutatások 1990-2001 közötti eredményeiról (Twelve Years. Comprehensive Studies about the Results of Transylvanian Hungarian Scientific Research between 1990 and 2001). Kolozsvár: Scientia.

EGYED, Péter. 2000. A rendszer. És üzenete (The System. And Its Message). In: Tonk, Márton-Laczkó, Sándor (eds), Böhm Károly és a „kolozsvári iskola”. A kolozsvári Böhm Károly Nemzetközi Konferencia elöadásai (Károly Böhm and the 'Kolozsvár School of Thought'. Papers Presented at the International Károly Böhm Conference in Kolozsvár). Kolozsvár-Szeged: Pro Philosophia. 
ERDÉLYI, János. 1885. A bölcsészet Magyarországon. (Philosophy in Hungary). Budapest: Franklin Társulat.

HANÁK, Tibor 1981. Az elfelejtett reneszánsz. A magyar filozófiai gondolkodás századunk elsố felében (The Forgotten Renaissance. Philosophical Thought in the First Half of Our Century). Bern: Európai Protestáns Magyar Szabadegyetem. KIBÉDI VARGA, Sándor. 1980. Magyar és német filozófia (Az erdélyi és badeni iskola) (Hungarian and German Philosophy / The Transylvanian and the Baden Schools). In: Kibédi Varga, Sándor: A szellem hatalma (The Power of the Spirit). München.

KRÁLIK, Lajos. 1913. Egy gyermekkori barát Böhmről. Adalékok Dr. Böhm Károly életéhez (A Childhood Friend about Böhm. Glosses to the Life of Károly Böhm). In: Kajlós (Keller), Imre (ed.), Dr. Böhm Károly élete és munkássága (The Life and Work of Dr Károly Böhm), vol. I. Besztercebánya: Madách Társaság.

LACZKÓ, Sándor. 2004. A magyar filozófiai mûnyelv kialakulása Apáczaitól a 1920. század fordulójáig (The Evolution of Hungarian Philosopical Terminology from Apáczai to the Turn of the 19/20 ${ }^{\text {th }}$ Century). Mester, Béla-Perecz, László (eds), Közelítések a magyar filozófia történetéhez (Approaches to the History of Hungarian Philosophy). Budapest: Áron Kiadó.

MAKKAI, Sándor. 1925. Az erdélyi református egyházi irodalom 1850-tól napjainkig (Transylvanian Reformed Religious Literature). Kolozsvár: Erdélyi Múzeum-Egyesület.

MESTER, Béla. 2006. Magyar philosophia. A szenvedelmes dinnyésztól a lázadó Ikaroszig. (Hungarian Philosophia. From the Fervid Melon Grower to the Rebellious Icarus). Kolozsvár-Szeged: Pro Philosophia.

TONK, Márton. 2002. Idealizmus és egzisztenciafilozófia Tavaszy Sándor gondolkodásában (Idealism and Existentialist Philosophy in the Thought of Sándor Tavaszy). Kolozsvár-Szeged, Pro Philosophia.

2015. The Reception of Kant by Sándor Tavaszy and The Klausenburg School. Violetta L. Waibel (ed.), Detours. Approaches to Immanuel Kant in Vienna, in Austria, and in Eastern Europe. Vienna: Vienna University Press, 212-216.

VERES, Ildikó. 2003. A kolozsvári iskola I. (The Kolozsvár School of Thought I.) Miskolc: Bíbor.

VERESS, Károly. 2003. Egy létparadoxon színe és visszája. Hermeneutikai kísérlet a nem lehet-probléma megnyitására (The Face and the Reverse Side of a Life Paradox. Hermeneutical Attempt at Opening the 'Not Possible' Debate). Kolozsvár: Pro Philosophia. 